\title{
Estambul otomano de Juan Goytisolo: lo propio y lo ajeno
}

\author{
Patricia LUCAS \\ Consejo Superior de Investigaciones Científicas \\ patricialucasalonso@gmail.com
}

Recibido: 5 de abril de 2011

Aceptado: 4 de mayo de 2011

\section{Resumen}

El viaje a Oriente ha generado un rico imaginario en la cultura occidental. En Estambul Otomano, Juan Goytisolo aborda el tema acercando la ciudad y su pasado al visitante europeo contemporáneo. Revisa los tópicos recogidos por los viajeros y nos muestra cómo, en muchos casos, se buscó en la ciudad una cabeza de turco en la que expiar algunos de los miedos propios. El artículo se propone detectar y analizar las estrategias intertextuales que Goytisolo emplea para enriquecer la visión tópica de la ciudad y conectar el mundo otomano con el contemporáneo. El autor busca testimonios que aportan otra mirada, como las cartas de lady Montagu o las citas del Viaje de Turquía; y por otra parte, recurre a la comparación del mundo turco con el occidental. El viaje a Estambul se convierte así en un acercamiento a lo exótico, pero también en una experiencia reveladora de lo propio.

Palabras clave: Estambul, Goytisolo, Montagu, Viaje de Turquía, intertexualidad.

Title: Juan Goytisolo's Ottoman Istambul: personal and external perceptions

\section{Abstract}

The journeys to the East have generated a rich imagery in Western culture. Juan Goytisolo's Ottoman Istanbul addresses this issue introducing the city and its past to the contemporary European visitor. He reviews the clichés collected by travelers and shows us how the city has been used in many cases as a scapegoat for personal fears. This paper aims to detect and analyze the intertextual strategies used by Goytisolo to enrich typical views of the city and to connect the Ottoman world to the contemporary one. The author looks for testimonies that provide us with different points of view, such as the letters of Lady Montagu or quotations from A Trip to Turkey. On the other hand, he compares the Oriental and Western worlds. Traveling to Istanbul thus becomes a way to approach this exotic universe, but also a self revealing experience.

Keywords: Istambul, Goytisolo, Montagu, A Trip to Turkey, intertextuality.

\section{Índice}

1. Goytisolo: viajar a Estambul, a su pasado y sus textos

2. Citas y referencias: viajar a través de testimonios ajenos

2.1. Los tópicos del viaje a Constantinopla

2.2. Cabeza de turco

2.3. En busca de otras miradas: Lady Montagu y el Viaje de Turquía

2.4. Comparación con lo propio

3. Estambul otomano: lo propio y lo ajeno 


\section{Goytisolo: viajar a Estambul, a su pasado y sus textos}

Juan Goytisolo (Barcelona, 1931) es uno de los escritores españoles cuya obra remite con mayor frecuencia a los mundos árabe, islámico, otomano y oriental. Basta revisar el índice de sus Obras completas (Goytisolo 2005-2010) para observar que, tanto en ensayos como en magníficas novelas, estos temas aparecen de manera recurrente. Como muestra resulta suficiente la mención de algunos de los títulos de sus textos ensayísticos: Crónicas sarracinas, De la Ceca a la Meca. Aproximaciones al mundo islámico, Aproximaciones a Gaudí en Capadocia o Lectura del espacio en Xemaá-El-Fná. En Estambul otomano, publicado originalmente en 1989 y reeditado con posterioridad en una colección de libros de viajes (Goytisolo 2003), el autor aborda el tema de la visita a Estambul y el viaje a Oriente.

"'¿Cómo escribir sobre Constantinopla si todo ha sido dicho?', se lamentaba, no sin razón, a mediados del siglo XIX, uno de los autores románticos adeptos al sistema de l'education par le voyage" (Goytisolo 2003: 9). Goytisolo comienza así su reflexión sobre la capital turca y el hecho de empezar con una cita nos pone frente al problema que la propia cita plantea. Hay tantas referencias sobre Estambul, hay tanto escrito, que incluso para decir que ya se ha dicho mucho sobre esta ciudad es posible hablar a través de una referencia ajena. Llegados a este punto parece que abordar un nuevo texto sobre la ciudad es más un trabajo de recopilación y catalogación que una labor de creación propia.

Es bien elocuente el título que Goytisolo da al primer capítulo de este libro de viajes: "Estambul: el texto urbano". Y es que es difícil hablar de esta ciudad a un posible viajero sin caer en algunos de los tópicos literarios consagrados: enclave entre Oriente y Occidente, crisol de culturas, punto de encuentro de civilizaciones... A lo largo del tiempo, una serie de expresiones parecen haberse adherido a esta ciudad que actualmente vemos como bisagra entre Europa y Asia. Una ciudad que para los viajeros románticos era la capital de las voluptuosas decadencias orientales y que, si viajamos un poco más atrás en el tiempo y llegamos a nuestro Siglo de Oro, veremos convertida en el centro de operaciones del Gran Turco. La imagen de la ciudad ha ido evolucionando a lo largo del tiempo, pero desde la perspectiva occidental mantiene casi siempre la característica fundamental de representar al otro.

El viaje a Oriente, en el que Estambul es una parada obligatoria, frecuentemente ha estado impregnado de intenciones pedagógicas y exploratorias. Conocer lo ajeno y, a la vez, ver de primera mano lo que otros han observado y contado, son dos de los propósitos fundamentales de la travesía. El viaje a Estambul es un viaje hacia el otro, pero también un viaje a través de otros, a través de todo lo que los viajeros anteriores a nosotros han descrito. Más que a ver, muchas veces se va allí a reconocer, a buscar en la 
realidad lo que se ha leído en los textos, por eso "aproximarse a Estambul significa ante todo embeberse en un corpus escrito" (Goytisolo 2003: 9).

El viaje que se nos plantea no es ya un mero desplazamiento en el espacio, sino una indagación textual que nos llevará también al pasado, no en vano el libro se titula Estambul otomano. Anteriormente hemos calificado el texto de Goytisolo como libro de viajes y, de hecho, la edición del 2003 está publicada en una colección dedicada a ese género. Sin embargo, cabría preguntarse qué tipo de viaje es este que realiza Goytisolo, el cual, a lo largo de todo el libro, no se mueve de la capital turca.

La ciudad deja de convertirse en el final de un itinerario, en un destino, y se transforma en un territorio que se explora en su presente $y$, sobre todo, en su pasado, en esa época otomana a la que se alude en el título. Al viaje en el espacio se superpone el viaje en el tiempo. En la exploración urbana, más que el recorrido físico en sí, empieza a contar lo histórico y lo libresco, y es quizá por eso que este texto se convierte en un perfecto compañero para viajar a una ciudad a la que, todavía hoy, el visitante parece acercarse buscando reminiscencias de tiempos remotos.

\section{Citas y referencias: viajar a través de testimonios ajenos}

"La realidad importaba menos que la fidelidad a la imagen previa del adversario, la adaptación a las convenciones del género y leyes de verosimilitud" (Goytisolo 2003: 10). Cuando se escribe tanto sobre algo, en este caso una ciudad, puede llegar a ocurrir que las palabras acaben por comerse a la propia realidad física. El viajero busca en la ciudad real que visita el rastro de lo que le han contado y a su vez, cuando regresa y relata su experiencia a otros posibles viajeros, su narración se ajusta más que a lo que ha visto, a lo que ya sabía de antemano.

Goytisolo nos advierte de este fenómeno y señala cómo, en relación a Estambul, este mecanismo ha generado toda una serie de tópicos occidentales adjudicados una y otra vez a la ciudad turca. En los años de Lepanto, Constantinopla era la capital del Gran Turco, la sede de un imperio tiránico y cruel, la base de operaciones del enemigo. "Durante el periodo de esplendor del Imperio otomano la imagen dominante del turco en Occidente es la de un ser bárbaro, feroz, cruel y sanguinario, entregado a los placeres carnales y el vicio nefando de la sodomía" (Goytisolo 2003: 76).

En la época romántica, cuando el poder otomano había perdido peso en la escena internacional y se hablaba de él como del hombre enfermo de Europa, la ciudad se muestra a los ojos de los viajeros como una especie de odalisca tentadora y decadente. La imagen de la crueldad imperial se transforma en una sugerente ensoñación oriental cuando el poder turco decae y deja de ser percibido como una 
amenaza por los occidentales: "El cambio de perspectiva es completo $y$, al temor inspirado por la prevención y desconocimiento, sucede una visión más objetiva, no exenta a veces de real simpatía y admiración" (Goytisolo 2003: 76-77). Actualmente, en estos tiempos de globalización y alianza de civilizaciones, con frecuencia se habla de la ciudad como puente entre Oriente y Occidente.

Parece que en cada momento Europa forja una imagen de Estambul acorde con la situación histórica, una imagen que los viajeros se ven casi obligados a buscar en la ciudad cuando la visitan y que, por otra parte, es la imagen que alimentan y reproducen con sus crónicas a la vuelta del viaje. Se viaja a Estambul para ver la ciudad, pero también se viaja de oídas, a través de los relatos de otros viajeros. Como veíamos antes, se generan tópicos repetidos una y otra vez, que se han ido modificando lentamente, al compás de los cambios en la cultura occidental ${ }^{1}$. Unos tópicos que además suelen acompañarse de un rico imaginario visual que ha ido cambiando con el tiempo y que nos permiten, todavía hoy, viajar gráficamente a Estambul en busca de Bizancio (Aguado Blázquez 2007).

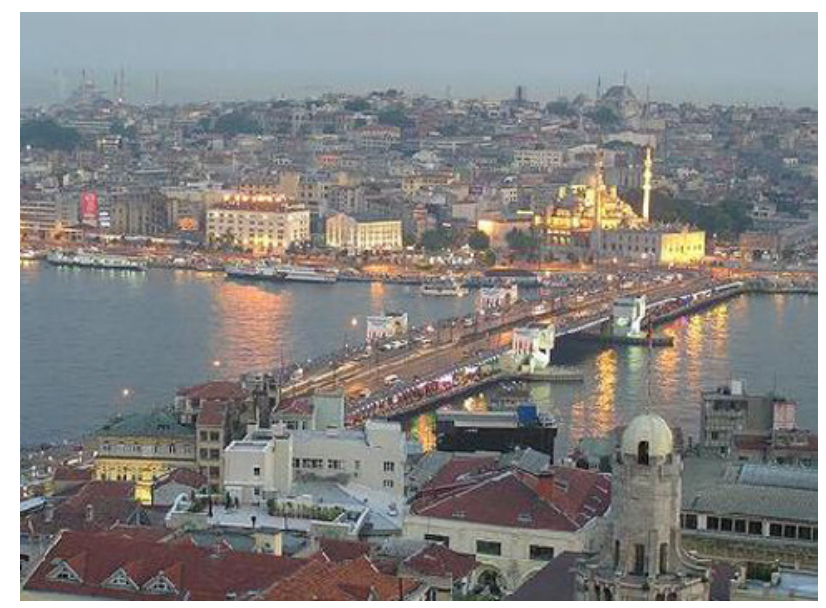

Fuente: enlamaleta.es

Figura 1. La ciudad como puente entre Oriente y Occidente

Ocurre, sin embargo, que a lo largo del tiempo unas ideas no han suplantado a otras por completo, sino que más bien los tópicos se han ido superponiendo. Al responder más a la mítica occidental que a la cambiante realidad estambuleña, las distintas percepciones han podido mantenerse vigentes simultaneamente en el imaginario

\footnotetext{
${ }^{1}$ Este imaginario de lugares comunes se refleja frecuentemente en las fotografías y dibujos asociados a la ciudad. Los tópicos visuales retratados en las ilustraciones seleccionadas, aparecen ligados al término Estambul entre las treinta primeras entradas de uno de los principales buscadores:

http://www.google.es/images?hl=es\&q=estambul\&um =1\&ie =UTF-

$\underline{8 \& \text { source }=0 g \& s a=N \& t a b=\text { wi } \& \text { biw }=1280 \& b i h=909}$ [Consulta: $29 / 03 / 2011$ ].
} 
colectivo, dando además lugar a una nueva imagen mítica de la ciudad, la de ese Estambul complejo, laberíntico y diverso que muchas veces se compara con un palimpsesto. En Aproximaciones a Gaudí en Capadocia, otro texto de Goytisolo en el que aborda el tema del viaje a Turquía, es precisamente ese el título que da al capítulo dedicado a Estambul: "La ciudad palimpsesto".

La yuxtaposición de planos históricos y étnicos de la gran urbe propicia desde luego la existencia de colisiones espaciotemporales, fenómenos de hibridación y mezcla dinámica de discursos que representan a mis ojos el sello inequívoco de la modernidad. (Goytisolo 2002: 109)

La realidad arqueológica local, en la que los distintos sustratos históricos parecen acumularse ad infinitum, apoya sin duda esta imagen. Pero quizá, el acierto de la comparación con el palimpsesto más que en la idea de superposición está en la referencia implícita a lo textual. En la realidad física de la ciudad se superponen capas históricas, todos los edificios parecen estar cimentados sobre los restos de otros. De la misma manera, casi todos los testimonios de los viajeros, al referirse a los temas y lugares de visita obligada, parecen beber de textos anteriores. En ocasiones parece que los viajeros calcan frases de crónicas y descripciones anteriores, generando un imaginario oficial que en cierto modo Goytisolo pretende cuestionar en su presentación de la ciudad turca. Se podría hablar incluso de un intento de negación de esos mitos, de una mitoclastia, en un sentido análogo al que se aplica para la labor de Américo Castro con respecto a los tópicos de la cultura hispánica (Castro, Goytisolo y Escudero 1997: 45).

\subsection{Los tópicos del viaje a Constantinopla}

El texto de Goytisolo recoge buena parte del imaginario asociado a Oriente. Los tópicos que los distintos viajeros han ido forjando sobre Estambul aparecen en la narración unas veces para ser confirmados y otras para ser contradichos, pero su sola mención sirve para sugerir al lector esa atmósfera oriental que probablemente se busca en el libro de viajes. El componente visual de muchos de ellos evoca en la mente del lector imágenes conocidas sobre Estambul y, de manera más general, sobre Oriente.

Al recurrir a testimonios ajenos y emplearlos citando las fuentes, Goytisolo se ahorra caer él mismo en el tópico, sin privarse, por otra parte, de evocarlo. Este recurso a la intertextualidad enriquece la narración, al incluir en el texto la dimensión histórica de la imagen de Estambul, o al menos de esa imagen que en cada época se ha ido forjando y popularizando en Europa. Para complementar esta visión el autor recurre además a distintos estudios históricos 
sobre el imperio otomano (Mantran 1989) o sobre aspectos sociales o religiosos del mundo islámico (Lewis 1986; Dijaït 1990).

Se describe la ciudad como un laberinto, se habla de los perfiles de su arquitectura de alminares, del mundo sugerente del hammam, la gastronomía o la vida de las mujeres turcas... las constantes del imaginario oriental no pueden faltar en un libro de viajes. Pero el hecho de citar constantemente las fuentes, nos avisa ya del origen occidental que muchas veces tienen algunos de los tópicos consagrados por la tradición viajera. Goytisolo no evita la evocación de la imagen romántica de la ciudad, pero cuando la presenta, cita inmediatamente a viajeros como Gautier o Lamartine, situando así esa visión de Estambul dentro de la historia del pensamiento occidental.

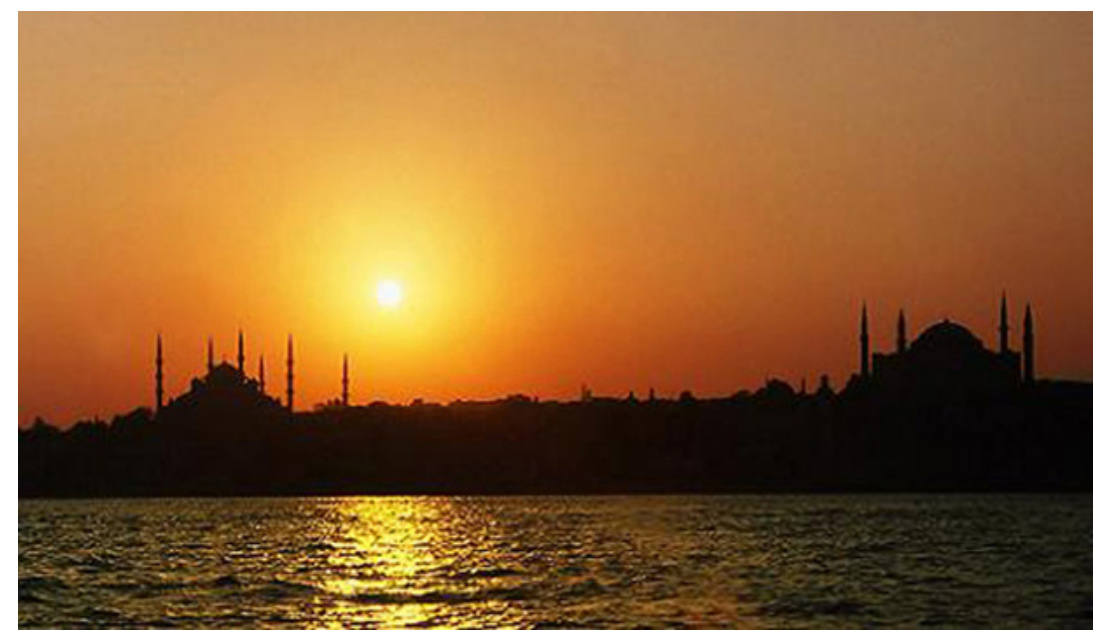

Fuente: Vuela viajes

Figura 2. El perfil de la ciudad, otro tópico visual

Este recurso a lo diacrónico se convierte en un elemento de gran importancia en el relato pues, de la mano de la curiosidad por lo exótico, el texto genera en el lector el interés histórico. Viajamos a otro espacio, a Estambul, pero también a otro tiempo, y este segundo alejamiento aporta para el lector occidental una nueva dimensión al viaje. Por ejemplo, cuando Goytisolo nos presenta las especialidades de la cocina turca, cada vez más conocidas para el público occidental, no solo nos muestra los platos, sino que se remonta a los orígenes otomanos de esa gastronomía. Se apoya en textos históricos de autores como Robert Mantran, Ahmet Refik o Evliya Çelebi, en los que se nos presentan los kabap-shish, döner, kefta, los rellenos de hojas de parra, pimiento o berenjena, los mezeler, los pilav de arroz... La evocación culinaria, típica de las guías de viaje, se vuelve así doblemente curiosa al impregnarse de evocaciones históricas.

A la hora de lograr este propósito resulta especialmente relevante el recurso al Viaje de Turquía. Se trata de un diálogo castellano del XVI en el que uno de los personajes, Pedro de 
Urdemalas, relata su viaje a Oriente a otros dos conversadores, Matalascallando y Juan de Voto a Dios. Al abordar este testimonio, Goytisolo emplea la cita extensa, cede la palabra a estos conversadores durante un par de páginas, y deja que sea Pedro el que de manera directa nos muestre la impresión que un castellano de la época se llevó de la gastronomía turca. La extrañeza, el gusto y la opinión sobre los manjares exóticos, un elemento típico de la narrativa de viajes, se enriquece cuando el viajero al que vemos enfrentarse a los distintos platos no es un contemporáneo nuestro, sino un hombre del Renacimiento.

Por otra parte, como hace notar Fernando García Salinero en la introducción de su edición del Viaje de Turquía: "Está fuera de duda que el autor de la obra imitó, copió y transcribió párrafos enteros de diversas obras que tratan de Turquía y los turcos" (Anónimo 2002: 36). Las propias fuentes a las que acude Goytisolo en sus citas son a su vez discursos intertextuales que recogen distintas tradiciones de la literatura de viajes.

Por ello, en vez de presentarnos un viaje propio en el que se reflejen de nuevo los tópicos de la expedición a Oriente, Goytisolo opta por presentar abiertamente viajes ajenos, especialmente aquellos que han ido generando el corpus escrito en el que se han forjado esos tópicos. Es así como aparece en el texto la mención del viaje a Oriente de Jan Potocki o los testimonios románticos de Gautier y Lamartine. Goytisolo nos lleva en su texto de visita al típico barrio de Eyup y nos sienta en el café de Pierre Loti, pero ese trayecto no lo hacemos solo de su mano, sino también con todos aquellos que antes han estado allí y han hecho populares en Occidente esos lugares estambuleños. Viajamos así a través de unos textos que constantemente se evocan y citan en el hipertexto de Goytisolo. Se trata de una estrategia narrativa similar a la que Orhan Pamuk emplea en Estambul: ciudad y recuerdos (Pamuk 2007), cuando superpone a sus evocaciones personales de la ciudad, la memoria rescatada a través de los distintos relatos y testimonios históricos.

No son un testimonio directo, pero aún así, aunque sea como evocación de una tradición escrita, los tópicos del viaje a Oriente aparecen en el texto. Junto a lo gastronómico, lo comercial es otro de los asuntos que se repiten en el relato de viajes. Si en el primer caso el kebab era el tópico obligado, ahora será el Gran Bazar la referencia imprescindible. Para describirlo Goytisolo vuelve a recurrir a la imagen del laberinto. La evocación tópica y sensorial del lugar, de sus olores, colores, fuentes, montañas de especias y telas vaporosas, se cuela también a través de testimonios ajenos. La mención al paseo urbano y comercial le lleva a nombrar a Baudelaire y Walter Benjamin, el intento de documentarse históricamente le hace citar otra vez a Mantran, la evocación romántica viene de la mano de las visitas de Gérard de Nerval a los caravanserallos y la visión castellana 
e histórica del lugar proviene otra vez de Pedro de Urdemalas. Goytisolo recurre en varias ocasiones a los mismos viajeros, en ese sentido su texto tiene algo de collage de referencias ajenas.

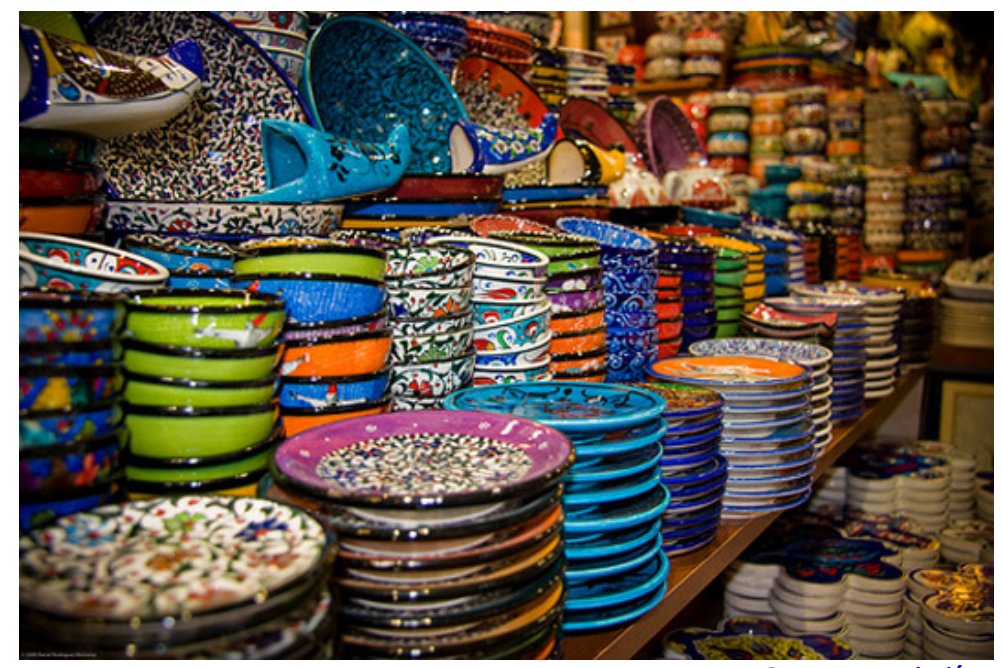

Fuente: $\underline{3 \text { viajes al día }}$

Figura 3. La cita obligada al comercio colorista en el Gran Bazar

La pertinencia de las citas, el contraste y el diálogo que generan entre ellas, es uno de los principales recursos del texto para cargar de interés la mención a los consabidos tópicos del viaje a Oriente. Por otra parte, el recurrir al testimonio de viajeros occidentales nos permite, no solo conocer el mundo exótico que describen, sino también la mirada que la sociedad occidental de la época tenía de esas costumbres ajenas. En estas citas no solo se retrata la ciudad que visita el viajero, sino también la mentalidad de su lugar de procedencia.

Al abordar el asunto del baño turco, otro de los lugares comunes obligatorios del viaje a Estambul, Goytisolo cita de nuevo el Viaje de Turquía. Junto a la encendida defensa que Pedro de Urdemalas hace del baño: "Yo mesmo lo hazía cada quinze días, y hallábame muy bien de salud y limpieza, que acá hay gran falta", la respuesta de sus interlocutores nos deja ver a las claras cuáles eran los hábitos de higiene en el Occidente europeo: "MATA, JUAN: Es cosa dañosa y a muchos se ha visto hazerles mal" (Goytisolo 2003: 122).

Conocer lo ajeno se convierte así en una forma de cuestionar lo propio. Por eso, cuando esta comparación se lleva al terreno de la vida de las mujeres turcas, otro de los tópicos del viaje a Oriente, se recurre a un testimonio femenino. A la idea extendida de la reclusión y falta de libertad de las mujeres orientales, Goytisolo opone el testimonio de Lady Montagu. Se trata de una viajera británica que llegó en el XVIII a Estambul acompañando a su marido diplomático y que dejó en sus cartas un vivo retrato de los lugares que visitaba. 
Lady Montagu habla de la libertad que para muchas mujeres supone la ropa que las oculta por completo y les permite moverse por la ciudad sin ser identificadas. Ella misma, en el siglo XVIII, se plantea ya si el corsé y la estricta etiqueta social femenina de la época son más o menos liberadoras que estas costumbres orientales. La visión de lo ajeno le sirve para reflexionar sobre lo propio y, puesto que esa parece una de las intenciones del texto de Goytisolo, no nos extraña que las cartas de esta viajera aparezcan abundantemente citadas.

El testimonio de Lady Montagu sobre las costumbres femeninas turcas se refuerza también con otra mención al Viaje de Turquía. Pedro de Urdemalas coincide en señalar la libertad que para muchas mujeres supone el hecho de ir ocultas por la calle, de resultar desconocidas, lo que según él, les permite ser infieles a sus maridos y concertar citas amorosas con bastante independencia. Llegados a ese punto, dejamos de saber bien si la mención de Urdemalas responde más a la realidad de Constantinopla o al ensueño que el español del Siglo de Oro podía albergar con respecto a la libertad de costumbres orientales. El relato de esta vida femenina libre, lejos del mundo estricto de la honra, lleva inevitablemente al asombro a Matalascallando, que queda fascinado ante las posibilidades de encuentro sexual en ese nuevo universo: "MATA: Desa manera no hay que preguntar si hay putas". La respuesta de Urdemalas, sin embargo, le hace ver que quizá ha llegado demasiado lejos en su ensueño, y que Constantinopla no es, en realidad, tan distinta en ese sentido a las ciudades europeas conocidas por ellos. "PEDRO: No penséis que tiene que haber pueblo en el mundo sin putas y alcauetas, y en los mayores pueblos más" (Goytisolo 2003: 35).

En Constantinopla las cosas son distintas, pero no tanto. El diálogo entre las costumbres propias y los hábitos ajenos, otro de los tópicos literarios de los libros de viajes, se convierte en el texto de Goytisolo en una reflexión histórica. El recuento de las experiencias ajenas sirve para completar el retrato de la ciudad, pero también para retratar a los que la han visitado. El viaje, por otra parte, hace posible una nueva mirada de los hábitos propios. Como dice Hugh Thomas en el prólogo que precede a la edición española de las cartas de Lady Montagu: "A Mary le gustaba vivir en el extranjero, tal como han hecho siempre muchos otros compatriotas ingleses, aunque no sea más que para ver a su país desde la perspectiva adecuada" (Montagu 1998: 22). Si el turco se presenta como el otro, el retrato que de él hacen estos viajeros históricos se convierte en un espejo de lo propio, de nuestra tradición, hábitos, costumbres y miedos. 


\subsection{Cabeza de turco}

"MATA: Parésçeme que esos señores estarán muy seguros de ser cornudos" (Goytisolo 2003: 35). Esta es una de las respuestas de Matalascallando al relato que hace Pedro de Urdemalas sobre la vida libre de las mujeres orientales. Goytisolo recoge este testimonio que ilustra bien cuál ha sido una de las actitudes occidentales típicas al relatar el viaje a Oriente y que él quiere poner de manifiesto en su texto. Se trataría de una idea similar a la que se expone en el libro Europa y el Islam (Dijaït 1990). En ocasiones, se han colocado en el otro, en el turco, aquellas actitudes o hechos que se rechazan o se temen en uno mismo. De este modo, la descripción del turco pasa a ser en buena medida un reflejo de los miedos y complejos propios. La preocupación de Matalascallando es perfectamente coherente con el universo moral de la España de la honra. Tampoco es de extrañar que en el Siglo de Oro las referencias a Estambul aludan a lo que entonces se consideraba el vicio nefando.

"PEDRO: La más çelosa jente son de quanta hay y con gran razón, porque como por la mayor parte todos son buxarrones, ellas buscan su remedio" (Goytisolo 2003: 43). El relato del viaje a Oriente realizado por los occidentales, pasa así de ser una muestra de lo exótico, a ser un reflejo de la mentalidad propia. La forma en que los viajeros hablan de Estambul, en muchas ocasiones, los retrata más a sí mismos que a los propios estambuleños.

La retórica de la alteridad empleada en Europa con respecto a los otomanos impone sus reglas y avasalla la experiencia y los datos reales: en la medida en que el turco es la imagen invertida del europeo, su inversión sexual debe ser regla y no excepción. (Goytisolo 2003: 44)

A veces, en estas descripciones queda más clara la forma de pensar del occidental que visita Constantinopla, que la propia realidad del imperio otomano. La realidad, por otra parte, se percibe a través del tópico literario y parece adaptarse para adecuarse a lo que ya se ha escrito o contado sobre el tema. Goytisolo nos hace ver que los occidentales, durante mucho tiempo, han buscado una cabeza de turco en la que expiar sus miedos y pecados, y la propia expresión es bien reveladora del lugar donde la encontraron. Como ya en 1978 exponía Edward Said en Orientalismo, las imágenes de la alteridad que se han ido formando en occidente no son ajenas a los mecanismos del poder y los procesos históricos (Said 2002). El turco, primero enemigo poderoso y luego parte del Oriente decadente, ha cumplido en ocasiones la función de encarnar al otro. Al representar las costumbres distintas a las oficialmente propias, sus hábitos aparecen muchas veces expuestos y criticados como algo condenable y ajeno. 


\subsection{En busca de otras miradas: Lady Montagu y el Viaje de Turquía}

En Estambul otomano, Goytisolo nos advierte del poder deformador de ciertos tópicos sobre el exotismo y la diferencia de Constantinopla con respecto a Occidente. Nos los presenta como materia literaria que puede resultar atractiva a la hora del viaje, pero también intenta hacernos pensar sobre la falta de veracidad de muchos de ellos. Para lograr esto, presta especial atención al testimonio de dos viajeros occidentales que ya hemos mencionado: el autor anónimo del Viaje de Turquía, ese diálogo español del XVI que venimos citando, y las cartas de Lady Mary Wortley Montagu.

Buena parte del imaginario actual sobre Estambul es de raíz romántica, autores como Gautier, Nerval, Flaubert, Du Camp o Lamartine junto a las imágenes orientales de los pintores decimonónicos, han sembrado el imaginario occidental de odaliscas, intrigas y misterios de harén. A diferencia de los testimonios de estos hombres del XIX, estas dos fuentes responden a viajes realizados en otra época, los siglos XVI y XVIII respectivamente, y además uno de los testimonios, el de Lady Montagu, aporta un punto de vista femenino. Un dato relevante, si evaluamos las posibilidades reales de que el viajero en cuestión haya podido ser testigo del mundo privado de las mujeres estambuleñas. No parece tan fácil que todos esos hombres occidentales se colaran en los harenes y baños que describen como si hubieran conocido de primera mano. Urdemalas, como dice Goytisolo, parece que quiere hacernos creer que se ha adentrado en las estancias privadas femeninas como Pedro por su casa.

El interés del Viaje de Turquía no reside tanto en la posible veracidad de estas descripciones, una veracidad dudosa cuando habla de espacios restringidos o de ámbitos vedados a los hombres, sino en el hecho de que nos presenta la visión que un español tenía sobre Constantinopla en el siglo XVI, una época en la que las relaciones del mundo hispánico con el turco no eran especialmente amistosas. El hecho de que, en una época de enemistad implacable, la imagen de Constantinopla no aparezca completamente deformada bien puede ser uno de los motivos que hayan hecho de este diálogo erasmista un texto cuya atribución se discute aún entre los hispanistas. Se barajan opciones como la de Andrés Laguna, postulada por Bataillon, otros piensan en Cristóbal de Villalón, y finalmente Fernando G. Salinero (Anónimo 2000: 64) propone como probable la atribución a Juan de Ulloa Pereira.

El autor, en cualquier caso, se ha vuelto escurridizo de la misma manera que sus comentarios sobre el mundo turco son, en buena medida, ambiguos. Como hace notar Goytisolo, Urdemalas nos habla de la "sede de nuestro contrario y capital enemigo" pero a la vez dice cosas como que "[Roma, Venecia, Milán, Nápoles, París y 
León] no son tanto juntas, hechas una pella, como sola Constantinopla" (Goytisolo 2003: 103).

Su actitud hacia los turcos es bastante ambivalente. Como veíamos antes, en el texto se deja ver la posición oficial que ponía en el turco al enemigo y hacía de él la imagen de los vicios y perdiciones ajenas. Pero a la vez, en el diálogo podemos leer en boca de Pedro de Urdemalas opiniones mucho más favorables: "En lo que yo he andado [...] no he visto gente más virtuosa" (Goytisolo 2003: 77).

La técnica dialogada permite contraponer las dos miradas. Las réplicas de Matalascallando y Juan de Voto a Dios, en ocasiones, devuelven el texto a la oficialidad intransigente de la época. Pero de todos modos, las opiniones de Pedro de Urdemalas, que muestran una visión más abierta del mundo turco, quedan también reflejadas. Por eso no es de extrañar que Goytisolo acuda a ellas cuando quiera presentar una imagen del mundo otomano que se sale de los tópicos consagrados en Occidente. Las palabras de Urdemalas se convierten en un testimonio histórico que prueba que en Constantinopla no todo era como nos habían contado.

Como descubren con asombro y mal disimulada admiración los viajeros occidentales, Constantinopla brinda, frente a la intransigencia católica y sus hogueras inquisitoriales, un ejemplo de convivencia pacífica entre personas y grupos de origen y credo diversos. "La justicia del turco -dice Urdemalas- conoce igualmente de todos, ansi christianos como judíos y turcos". (Goytisolo 2003: 67)

De manera similar, Goytisolo recurre al testimonio de Lady Montagu cuando quiere mostrar un punto de vista distinto al tópico extendido en Occidente sobre la reclusión de las mujeres otomanas. Las cartas de esta singular viajera del XVIII nos dejan ver la curiosidad, apertura de mente y afán exploratorio de Lady Montagu. Acompañando a su marido, enviado a Constantinopla en misión diplomática, esta mujer atravesó Europa y llegó a Turquía cuando todavía este trayecto era una larga travesía que, a los ojos de los europeos, se presentaba llena de peligros.

Uno de los elementos que hacen especialmente valioso el testimonio es el punto de vista femenino, y no es tan solo una cuestión de mirada, sino que al tratarse de una viajera resulta mucho más verosímil el hecho de que haya visitado los espacios privados de las mujeres turcas, un terreno que parecía ciertamente vedado para esos viajeros masculinos que, sin embargo, los describen y retratan al detalle. El mundo del baño, que a los ojos de los hombres del XIX aparecía como un espacio de sensualidad oriental y decadencia atractiva, se presenta a Lady Montagu como un lugar de encuentro y esparcimiento para la comunidad femenina. Es el ámbito donde se reúnen, comentan y crean lazos de hermandad y complicidad. 
Sin embargo, el interés de las cartas de Montagu no es solo una cuestión de género, referida únicamente a sus apreciaciones sobre las mujeres otomanas. Si en el caso del Viaje de Turquía se dejaba entrever una parte del pensamiento español del XVI, en las cartas de Lady Montagu se puede apreciar ya un cierto desencanto con la vida de orden industrioso que el incipiente espíritu burgués estaba generando en Europa. Goytisolo recoge algunas palabras de esta viajera que dejan entrever cierta nostalgia por un mundo hedonista que parece perderse en Europa y buscarse, quizá todavía hoy día, en el viaje a Oriente: "Me inclino a creer que su idea de la vida es mejor", dice Lady Montagu al respecto (Goytisolo 2003: 78). Ya en el XVIII, las cartas de esta mujer dejan ver esa nostalgia del placer perdido que adquirirá peso en los relatos de las orientales románticas y que podemos encontrar también en el poema Sailing to Byzamtium de W. B. Yeats.

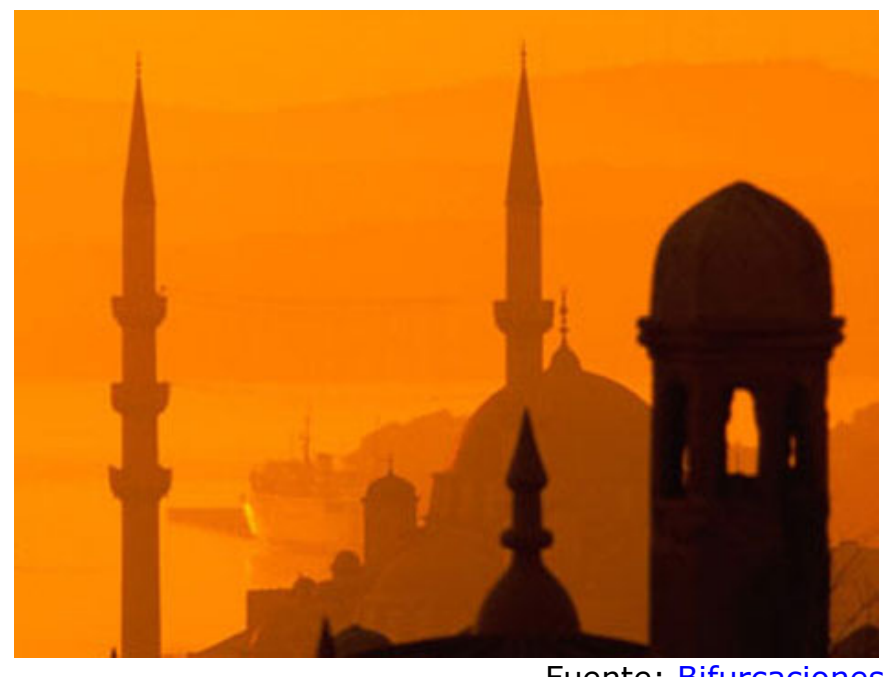

Figura 4. Estambul como ensoñación oriental

\subsection{Comparación con lo propio}

Los testimonios históricos con los que Goytisolo va trabajando nos hacen comparar constantemente lo que pensamos de Estambul con lo que vieron gentes de otras épocas. El viaje en el tiempo que se nos propone nos hace enfrentar el presente al pasado, pero también comparar el pasado europeo, y más concretamente hispánico, con el del mundo turco.

La idea de un cierto paralelismo entre ambas decadencias imperiales, la de la España de los Austrias y la del Imperio Otomano, se deja entrever al abordar distintos aspectos de la descripción de Constantinopla. El paralelismo parece ser unas veces económico: "La llegada masiva de oro y demás metales preciosos del Nuevo Mundo afectó, como en España, los modos de producción tradicionales" (Goytisolo 2003: 14), y otras veces social: "Como los cristianos viejos 
en la España tan finamente analizada por Américo Castro, los otomanos no admitían sino cuatro profesiones: administración estatal, ejército, religión y agricultura" (Goytisolo 2003: 16). Pero sobre todo parece ser un paralelismo en los movimientos de ascenso y decadencia.

"Como España en el ocaso de los Habsburgo, el Imperio descaecía en una especie de sueño del que solo la agresión exterior y su propia dislocación interior lo lograrían finalmente arrancar" (Goytisolo 2003: 91). Los tópicos del viaje a Oriente parecen incidir en todo aquello que es distinto y exótico, pero la consideración histórica de los fenómenos que realiza Goytisolo, a través de las citas, nos llevan hacia el terreno de las similitudes. En este sentido, dentro del mundo occidental, cobra especial interés la referencia a lo hispánico: "Un paralelo entre ambos imperios [el otomano y el español] a lo largo de los siglos XVI, XVII y XVIII sería desde luego tentador" (Goytisolo 2003: 17).

La comparación de lo que se ve en el viaje con lo propio y cercano, un recurso típico de este tipo de discursos, se emplea en el texto no solo entre hechos históricos, sino también con elementos contemporáneos. Se trata de un medio de aproximación del pasado oriental remoto al presente conocido por los lectores. Los hechos del pasado se explican por comparación con la realidad presente. Se intenta así acercar lo narrado a un receptor que se supone occidental y contemporáneo: "la topografía de Estambul era tan bien conocida por los lectores de 1600 como lo es hoy, gracias al cine, la de Nueva York o París" (Goytisolo 2003: 10).

Estas comparaciones, repetidas a lo largo del texto, pueden desencadenarse por diversos motivos: paralelismos de fechas, sucesos, tendencias históricas o incluso la simple similitud formal. Este es el caso del parecido que Goytisolo encuentra entre las pintorescas formaciones geológicas turcas y las obras del insigne arquitecto catalán en Aproximaciones a Gaudí en Capadocia (Goytisolo 2002).

Comparar lo ajeno con lo propio es un recurso frecuente en la narrativa de viajes, y podemos encontrárnoslo en los propios testimonios históricos que se citan y recopilan. La técnica no es nada nuevo, viene de lejos como es posible comprobar en el propio texto de Goytisolo. Así, a través del autor catalán escuchamos a Pedro de Urdemalas describiendo la riqueza de las tiendas del Gran Bazar mediante una comparación con lo que para sus oyentes, españoles del siglo XVI, era conocido y cercano: "Aquella joyería que veis en la plaza de Medina del Campo verlo heis todo en una sola tienda" (Goytisolo 2003: 97). 


\section{Estambul otomano: lo propio y lo ajeno}

A través de la recopilación de textos y testimonios ajenos, el libro de Goytisolo se convierte en imagen de la ciudad de Estambul. La acumulación de experiencias de distintos viajeros a lo largo del tiempo, así como la dimensión histórica de muchos de estos relatos, es en buena medida el reflejo textual de la propia realidad de la ciudad, mencionada tantas veces como un espacio de culturas superpuestas.

La imagen de la ciudad como laberinto, como mezcla variopinta de construcciones y proyectos urbanos, queda retratada en un texto que, como la propia Estambul, parece construirse mediante la sabia unión de elementos heterogéneos. El libro de viajes se nos presenta así como un discurso mixto en el que se da cabida a la cita, el diálogo, la carta, el ensayo, las referencias, etc.

A la hora de hablar de una ciudad de la que tanto se ha dicho, no se pueden ignorar los testimonios anteriores, la tradición literaria forma ya parte del paisaje urbano que pretende describirse. Pero por otra parte, repetir como propios los tópicos ya consagrados tampoco parece una opción viable. Ante esa encrucijada Goytisolo opta por "un género híbrido, como el que cultivan los verdaderos o falsos viajeros a Turquía y Oriente, crear el objeto de su narración a fuerza de engarzar con una sucesión infinita de referencias previas" (Goytisolo 2003: 11-12).

El viaje físico, conocer la ciudad de Estambul, se convierte así en una experiencia literaria y por tanto en un viaje en el tiempo, en este caso al pasado otomano de la ciudad. El libro de viaje cumple así la misión de ampliar la experiencia física de la visita mediante la continua alusión a la tradición literaria. El paseo propio se completa con los testimonios ajenos, unos testimonios que, por otra parte, son los que ya habían actuado, en muchos casos, como acicates o tentaciones sugerentes antes de emprender el viaje. Por otra parte, a esa tradición literaria se suma la experiencia personal, la propia biografía, no es casual que sea un barcelonés el que encuentre a Gaudí en Capadocia (Goytisolo 2002).

Goytisolo recurre a la tradición del viaje a Oriente y a la imagen de Estambul forjada por ella, pero a la vez nos advierte de su condición de realidad literaria, que no tiene por qué coincidir exactamente con la realidad física que encontraremos al llegar a Estambul. La literatura de viajes se nutre en muchas ocasiones de tópicos que de un viajero a otro se van repitiendo y que terminan por ser los elementos que los visitantes buscan al llegar al lugar que visitan. Generalmente estos elementos se persiguen en el viaje hasta que se da con ellos, hasta que se capturan en un apunte o una fotografía que se mostrará al regresar a casa, y que añadirá así un grano de arena más en la ya enorme montaña del tópico viajero referido a la ciudad de Constantinopla. 


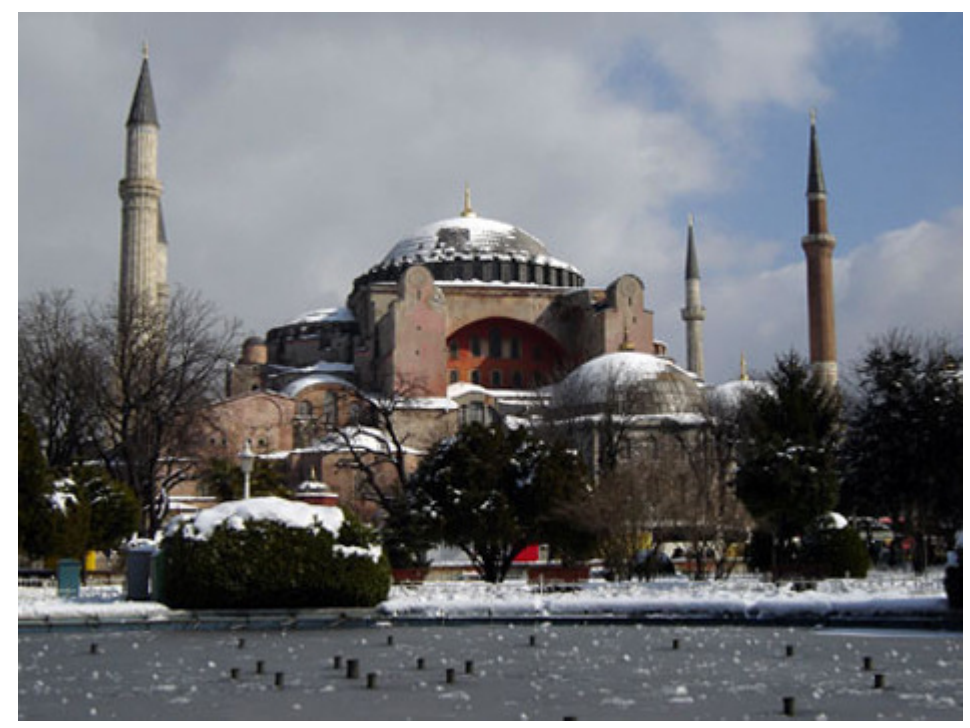

Fuente: Las escapadas, blog de viajes

Figura 5. La imagen recurrente de Santa Sofía

Este círculo infinito puede llegar a hacer del viaje una experiencia paradójica en la que el contacto con lo real, lo que uno ve en la propia ciudad, queda de lado frente al enorme peso de la realidad literaria. La sugerencia de lo escrito es tanta, que se ha creado ya un mundo aparte de la propia ciudad física. "La fidelidad a la verdad se mide en la exactitud de la copia: el turco real es el que figura en los libros" (Goytisolo 2003: 12).

Esta reflexión de Goytisolo nos pone frente al problema de la realidad y la autenticidad en la experiencia del viaje y nos hace plantearnos en qué medida aquellos elementos que se consideran más propios de un lugar, lo son porque efectivamente son protagonistas de la vida allí, o lo siguen siendo porque en algún momento fueron inmortalizados por esa tradición viajera que se perpetúa en los textos literarios.

En estos tiempos, en los que las ciudades se ofertan al turismo como un producto de consumo, cabría preguntarse también en qué medida algunos lugares deciden mostrarse deliberadamente de acuerdo con esas imágenes consagradas por la tradición viajera. No es ya solo, como nos dice Goytisolo, que el turco que aparece en los textos sea tan real como el que encontramos por las calles de Estambul, sino que podría llegar a suceder que ese turco real, la ciudad que habita y tantos otros enclaves con aspiraciones turísticas, hayan decidido adecuar su imagen a la del tópico consagrado por los distintos viajeros, solo con la intención de satisfacer así las demandas visuales y las expectativas de los visitantes que se esperan.

Ante esta situación de mezcla entre lo real y lo imaginario, textos como el de Goytisolo resultan ilustrativos. Al citar continuamente las fuentes, el autor nos muestra el origen del tópico y 
sin renunciar a él ni a su sugerencia, nos da la medida de su valor literario, lo ubica históricamente y lo enmarca dentro de una corriente de evocaciones literarias para el viaje. El visitante llega a Turquía empapado de las imágenes forjadas por sus antecesores, unas imágenes que el occidental cree netamente orientales, pero que Goytisolo, al presentárnoslas de la mano de sus padres europeos, nos hacer ver que han sido forjadas por occidentales como Gautier, Gérard de Nerval o Lamartine.

Goytisolo nos advierte además de que en muchos casos la realidad de estas evocaciones sugerentes es fundamentalmente literaria, y que además, en ocasiones, lo que han hecho ha sido consagrar ciertas ideas tópicas sobre el turco, imaginado durante mucho tiempo por parte de los occidentales como la viva imagen de lo extraño, del otro.

Goytisolo reflexiona sobre la influencia que en la imagen occidental de Estambul ha tenido la consideración del turco como representante de la alteridad. Era el enemigo en el Siglo de Oro y posteriormente, cuando la vida burguesa y el trabajo industrial cobraban fuerza en Europa, el mundo oriental se convirtió en la imagen del hedonismo decadente o del placer perdido.

El turco ha sido el otro al que Occidente ha mirado unas veces con recelo y otras con nostalgia. En este sentido, la mirada a Oriente, visto como un mundo exótico y lejano, unifica al Occidente europeo que, salvando sus diferencias locales, se presenta como un bloque homogéneo de costumbres, creencias y hábitos de vida. Goytisolo recoge al respecto una reflexión del ensayista tunecino Hichem Dijaït:

"[...] Porque se cerró al Otro, Occidente se dividió en sí mismo y con ello admitió el ser del Otro; por haber inventado la tolerancia y admitido en su seno cuerpos ajenos permanentes, activos y amenazadores, el Islam, a la inversa, obligado a defenderse, se contrajo y afirmó contra el Otro". La teoría es plausible, pero, para aceptarla plenamente, deberíamos contrastarla con el ejemplo español: el de una decadencia similar originada por razones opuestas. (Goytisolo 2003: 70-71)

Según este pensador habría sido la uniformidad occidental, el rechazo al otro, lo que habría llevado a la fragmentación interna y a la aceptación final de la diferencia en Occidente. Mientras que en el mundo islámico el proceso habría sido inverso; la convivencia con el otro habría llevado finalmente a la contracción y afirmación de las costumbres propias. Goytisolo recoge esta idea de procesos opuestos, aunque nos advierte de que habría que compararla con ese paralelismo con lo hispánico que él mismo ha estado dejando entrever a lo largo del texto. 
Ante las palabras de Hichem Dijaït, citadas por Goytisolo, cabría plantearse también otro asunto. La reflexión sobre Estambul nos hace pensar en el hecho de que, a veces, la visión occidental sobre Oriente resulta tópica y uniformadora. En el juego de miradas cruzadas que el ensayista tunecino nos propone, es decir, en la mirada a Occidente desde Oriente, ¿podría ser que a veces sucediese lo mismo?

\section{Bibliografía}

AGUADO BLÁZQUEZ, Francisco A. (2007): Guía de Constantinopla: un viaje a Estambul en busca de Bizancio. S. L.: AFAB (Spania-Bizas) D. L.

ANÓNIMO (2000): Viaje de Turquía. Edición de Fernando G. Salinero. Madrid: Cátedra.

CASTRO, Américo; GOYTISOLO, Juan; y ESCUDERO, Javier (1997): El epistolario: Cartas de Américo Castro a Juan Goytisolo (1968-1972). Valencia: Pre-Textos.

DIJAÏT, Hichem (1990): Europa y el Islam. Madrid: Libertarias.

GOYTISOLO, Juan (2002): Aproximaciones a Gaudí en Capadocia. Barcelona: Península.

- (2003): Estambul otomano. Barcelona: Península.

- (2005-2010): Obras completas, vols. I-VIII. Barcelona: Galaxia Gutenberg / Círculo de lectores.

LEWIS, Bernard (1986): Laicisme et Islam. Paris: Fayard.

MANTRAN, Robert (1989): Histoire de l'Empire ottoman. Paris: Fayard.

MONTAGU, Mary Wortley, Lady (1837): Letters of the Right Honourable Lady Mary Wortley Montagu: written during her travels in Europe, Asia and Africa. Londres: Richard Bentley.

- (1998): Cartas desde Estambul de Lady Mary Wortley Montagu. Prólogo de Hugh Thomas. Barcelona: Casiopea.

- (2007): Life on the Golden Horn. London: Penguin Books.

PAMUK, Orhan (2007): Estambul: ciudad y recuerdos. Barcelona: Mondadori.

SAID, Edward (2002): Orientalismo. Madrid: Debate. 